and equinoxes. In this way, we might test the influence of the increasing (FebruaryApril) or decreasing (August-October) photoperiod, and insufficient (NovemberJanuary) or excessive (May-July) daylight.

Since Partonen \& Lönnquist do not report monthly frequencies, we cannot apply these criteria to the Finnish data. However, we have applied them to a Portuguese sample of 34 longitudinally followed bipolar patients (Pio-Abreu \& Pires, 1985), and to 178 female admissions for mania and depression (Boto et al, 1991). Both studies revealed a peak of bipolar episodes during the equinoctial periods, where depressions predominate from February to April, and manias between August and October. In contrast, mixed and switching episodes, as well as some unipolar depressions, tended to occur around the solstices.

Although these results are consistent with an extensive review by Wehr \& Rosenthal (1989), they may be idiosyncratic to Portugal. Since sunshine varies with latitude, more studies are needed worldwide in order to understand the problem better. However, it would be preferable if results were presented in terms of monthly frequencies, and not simply as the required figures for testing seasonality as conventionally defined.

Boto, l., Craveiro, A. \& Plo-Abreu, J. L. (1991) Maniase depressరes: distribuição sazonal e relação com factores climáticos. Psiquiatrio Clinico (Coimbro). 12, 171-174.

Partonen, T. \& Lönnqvist, J. (1996) Seasonal variation in bipolar disorder. Britush journol of Psychuoury. 169. 641-646.

Mo-Abreu, J. L. \&Pires, I. C. (1985) Incidência sazonal das psicoses afectivas bipolares. Psiquiatrio Clínico (Combro), 6. $18 \mid-188$.

Wohr, T. A. \& Rosenthal, N. E. (1989) Seasonality and affective illness. American fournol of Psychiatry, 146. 829-839.

J. L. Pio-Abreu Psychiatric Clinic, University Hospital of Coimbra. 3049 Coimbra, Portugal

\section{Terminology of learning disability}

Sir: Few would disagree with Reid (1997) that learning disability is not an ideal term. It may also be true that it was adopted by the Royal College of Psychiatrists simply for the sake of political correctness. This, however, even when coupled with the objection that the term contains no medical or psychiatric dimension, provides no adequate grounds for yet a further unwelcome change in terminology.

Mental handicap, the term generally discarded in the UK but nevertheless still favoured by Dr Reid and many others, remains less appropriate than learning disability for two important reasons. The first is, as Reid himself points out, because of the objections of those suffering from the condition and able to express an opinion. The second is the difficulty experienced by the general public in distinguishing between mental handicap and mental illness, largely because of the use of the word 'mental'. Not surprisingly, this confusion led to the assumption that mental handicap was primarily a medical problem. If now, instead, it is thought that the term learning disability implies that the condition is essentially educational, rather than register dismay we should instead throw our hats in the air. This description does after all contain a greater element of truth.

The problems of people with learning disability can be met only by a multidisciplinary approach. It is unlikely that the emphasis on the word 'learning' can diminish the contribution of medicine, particularly psychiatry, to the care of this group.

Reld, A. H. (1997) Mental handicap or learning disability. A critique of political correctness. British journol of Psychiotry. 170. 1

Gwyn Howells Belvedere House, Fort George, St Peter Port. Guernsey GYI 2S]

Sir: As Reid (1997) points out in his excellent editorial, no-one would wish to revert to the terms 'idiot' or 'imbecile'. None the less, it is interesting to note that these terms were themselves once euphemisms. In classical Greek the adjective idios means one's own, private or personal, and the noun idiot (idiotes) was a private as opposed to a public person. Idiot then came to mean someone without professional knowledge, and finally, in some post-classical Greek writers, "an ignorant person" (Liddell et al, 1961). 'Imbecile' comes from the Latin imbecillis, which means weak or frail. Perhaps in our own times terms such as 'intellectually disabled' will soon be found too stigmatising and replaced by 'intellectually differently abled'.

Underlying this absurd quest for ever newer euphemisms there would appear to be two implicit, but partly contradictory assumptions: first, that language is thought; and second, that the language we use determines what we think. There are several good reasons for believing that language is not thought, such as our awareness of not being able to put some of our own thoughts into words, problem-solving involving the manipulation of mental images (i.e. nonverbal thinking), the invention of words or neologisms to express new ideas for which no words previously existed, the phenomenon of ambiguity in language, etc. (Pinker, 1995). Thus, if language is not thought, the notion that language predetermines how we think loses much of its plausibility. It is our thought which contaminates the euphemisms, not the euphemisms which disinfect our thought. For these reasons also Reid is right: in the case of mental handicap or learning disability it is our attitudes which must change, not our terminology.

Liddell, H. G., Scott, R. \& Jones, H. S. (1961) A Greek English Lexicon. Oxford: Clarendon Press.

Pinker, S. (1995) The Longuage instinct. Harmondsworth: Penguin.

Redd, A. H. (1997) Mental handicap or learning disability. A critique of political correctness. British fournal of Psychiatry. 170.1 .

P. Crichton Department of Psychological Medicine, Royal Marsden NHS Trust, Fulham Road, London SW3 6]

\section{Valproate and neuroleptic medication}

Sir: Barnes et al (1996) point out the paucity of data on adjunctive use of valproate in the treatment of psychotic disorders only partially responsive to neuroleptics.

We have conducted an open trial of 17 out-patients (six male; mean age 34 ; s.d. 10 years) to ascertain whether valproate can be used to 'spare' neuroleptics in patients with bipolar disorder with psychosis $(n=13)$ and schizoaffective disorder $(n=5)$. All patients had been stabilised on neuroleptics for at least six months. Mean pre-valproate neuroleptic dose was $260 \mathrm{mg}$ chlorpromazine equivalents per day (s.d. $150 \mathrm{mg}$; range $25-$ 500 ). In the six months post-valproate, only two patients required ongoing neuroleptics, with doses of 100 and $200 \mathrm{mg}$ chlorpromazine equivalents daily (prior doses 200 and $500 \mathrm{mg}$, respectively).

This preliminary study, with the methodological limitations inherent in open, nonrandomised, non-blind designs, nevertheless raises the possibility of wider use of valproate to spare neuroleptics in patients with bipolar and schizoaffective disorders, and potentially schizophrenia as well (three further treatment-resistant schizophrenia patients have been commenced on valproate 